\title{
B-cell activity in children with malaria
}

\author{
Jackson C Korir ${ }^{1,2,3}$, Japhet K Magambo ${ }^{2}$, Joseph K Mwatha ${ }^{4}$ and John N Waitumbi ${ }^{\text {* }^{*}}$
}

\begin{abstract}
Background: Recent studies implicate deficiency of red blood cell (RBC) complement regulatory proteins (CR1 and CD55) in the pathogenesis of malarial anaemia. This study explored the involvement of B cell CD21, which has an analogous role to RBC CR1.

Methods: In a case control study conducted in Kisumu District hospital, western Kenya, children with severe malaria anaemia (SMA) and those with uncomplicated malaria (UM) were assessed by flow cytometry for B cells (CD20+) numbers, expression levels of CD21 and deposition of C3dg and by ELISA for soluble CD21 (sCD21). Paired $\mathrm{t}$ tests were used to determine statistical significance at $\mathrm{a}=0.05$.

Results: Children with SMA had significantly higher lymphocyte count $(9,627.7 \pm 8786.1$ SD vs. 5,507 \pm 2436 SD, $P$ $=0.04$ in the UM group) and the computed geometric mean of mature B-cell numbers based on the absolute lymphocyte count was significantly higher for SMA group: 1,823 (1,126 to 2,982, 95\% Cl) and 826.6 (564 to 1,220, 95\% Cl)] for UM group $(P=0.003)$. SMA group also had a higher percentage of CD20+ B cells $(26.8 \pm 9.75 D$ vs 20.9 $\pm 9.01 \mathrm{SD}$ in the UM) $(P=0.03)$, indicating considerable polyclonal B-cell activation. The CD21 median flourescence intensity was lower in the SMA $(246.4 \pm 87.4$ SD vs $369 \pm 137.7$ SD) $(P<0.0001)$, probably due to complement mediated shaving of CD21 by fixed tissue macrophages. The CD20+ B cells of SMAs had higher levels of the complement split product C3dg (18.35 \pm 10 SD vs $11.5 \pm 6.8$ S.D), $(P=0.0002)$, confirming possible role of complement in CD21 removal. Unexpectedly, the SMAs had lower levels of sCD21 (226.5 \pm 131.5 SD vs $341.4 \pm$ $137.3 \mathrm{SD}$ in the UM) $(P<0.0001)$, indicating that the shaved CD21 is not released to peripheral circulation.

Conclusions: These results implicate B-cell in pathophysiology of severe malaria that involves increased B-cell proliferation, increased complement deposition and subsequent loss of membrane-bound CD21. The loss of CD21 is not by the classical enzmatic cleavage.
\end{abstract}

\section{Background}

The global malaria burden remains enormous. According to the World Health Organization (WHO) report of 2008 [1], there were an estimated 247 million malaria cases and about 3.3 billion people at risk. Malaria has several manifestations ranging from asymptomatic parasitaemia in semi-immune individuals, to severe disease in susceptible populations that include children below five years, pregnant women and non-immune adults. In these individuals, severe malaria manifests in a variety of forms, including cerebral malaria, severe anaemia, metabolic acidosis, placental malaria and hypoglycaemia, among others $[2,3]$. Although these disease patterns have multiple causes, recent studies implicate acquired deficiency of RBC complement regulatory proteins such

\footnotetext{
* Correspondence: jwaitumbi@wrp-ksm.org

${ }^{1}$ Walter Reed Project/Kenya Medical Research Institute, Kisumu, Kenya

Full list of author information is available at the end of the article
}

as CR1 (CD35) and CD55 in pathogenesis of severe malaria anaemia (SMA) $[4,5]$. These proteins protect the $\mathrm{RBC}$ from destruction by inhibiting formation of the $\mathrm{C} 3$ convertases, thereby preventing the terminal polymerization of the membrane attack complex (MAC) [6].

Similar to RBCs, B-cells also bear complement regulatory proteins such as CR1 and complement receptor 2 (CR2, CD21). These receptors have been shown to be important in the binding of opsonized IC [7-9]. Studies with $\mathrm{C} 3 \mathrm{~b}$ opsonized tetanus toxoid and opsonized immune complexes have indicated that interaction of C3 fragments with CD21 allows non-specific B cells to participate in antigen presentation [10]. Co-ligation of CD21 with B-cell receptor (BCR) by C3d-taggged antigen also promotes the trafficking of antigen to processing compartments in the B cell and for more efficient production of antigenic-peptide/class II complexes [11]. CD21 is only expressed on mature B-lymphocytes [12]
C Biomed Central

C 2012 Korir et al; licensee BioMed Central Ltd. This is an Open Access article distributed under the terms of the Creative Commons Attribution License (http://creativecommons.org/licenses/by/2.0), which permits unrestricted use, distribution, and reproduction in any medium, provided the original work is properly cited. 
and because even modest changes in the level of expression is likely to affect the capacity of B cells to respond to antigenic stimuli $[13,14]$, the level of expression of CD21 is tightly controlled. Disease states that alter the expression of CD21 would, therefore, be expected to impact the host immunological responses.

Abnormalities of CD21 have been described in various diseases. In systemic lupus erythematosus (SLE), the expression level of both CR1 on RBCs [15] and CD21 on $B$ cells is reduced [16]. This decline is usually disease-mediated and not genetic $[17,18]$. Reduced expression of CD21 has also been observed in HIV-seropositive individuals. The effect malaria has on the expression of CD21 and the probable implication has not been explored.

CD21 also exist in a soluble form (sCD21) that is generated by shedding of the membrane-associated form and can be demonstrated in lymphocyte cultures and in plasma [19-21]. Elevated levels of sCD21 are seen in Bcell diseases such as chronic lymphocytic leukaemia (BCLL) [22], common variable immunodeficiency (CVID), Brutons's X-lined gamma-globulinaemia $[20,23]$ and Epstein-Bar-virus (EBV) malignancies [19].

Although proliferation of B cells is regulated, strong polyclonal B-cell response resulting in hyper- $\gamma$-globulinaemia and auto-antibodies secretion has been described in Plasmodium falciparum infections [24]. Studies by Donati et al. [25] identified the cystein-rich interdomain region $1 \alpha$ (CIDR-1 $\alpha$ ) of the P. falciparum erythrocyte membrane protein-1 (PfEMP-1) as responsible for the polyclonal activation. In this study, the involvement of $B$ cells during malaria was explored by comparing the Bcell numbers, levels of complement deposition, levels of membrane bound and sCD21 in groups of children with either severe or uncomplicated malaria.

\section{Methods}

This study was a hospital-based prospective case-control and details of the study, including ethical approvals, have been described previously [26].

\section{Determination of CD20+ cell population, expression level of CD21 and C3dg deposition}

A $50 \mu \mathrm{L}$ aliquot of each EDTA blood sample was placed into three wells (test sample, unstained control and isotype control) of a round-bottom, 96-well plate. To each well was added $200 \mu \mathrm{L}$ of wash buffer (PBS containing 1\% BSA and $0.1 \%$ sodium Azide). The re-suspended cells were centrifuged for three minutes at a $1,620 \mathrm{xg}$ and the supernatant discarded. Thereafter, the cell pellet was re-suspended in $100 \mu \mathrm{L}$ of $10 \%$ mouse IgG in PBS and then incubated for 30 minutes at room temperature. This was followed by three washes and the cell pellet re-suspended in $100 \mu \mathrm{L}$ of antibody cocktail comprising CD20PerCP (BD Pharmigen,
USA)/CD21PE (BD Pharmigen, USA)/C3dgAL488 (a gift from Prof. Ronald P Taylor, University of Virginia, Charlottesville, USA) at a final concentration of $1 \mu \mathrm{g} / \mathrm{mL}$ and mouse $\operatorname{IgG}_{1}-\mathrm{k}$ for isotype control well. For the unstained control, wash buffer was added followed by incubation for 30 minutes at $4{ }^{\circ} \mathrm{C}$. Thereafter, the cells were washed and the cell pellet re-suspended in $200 \mu \mathrm{L}$ of lysing buffer (150 $\mathrm{mM} \mathrm{NH}_{4} \mathrm{Cl}, 10 \mathrm{mM} \mathrm{NaHCO}_{3}$ and $1 \mathrm{mM}$ EDTA) for three minutes at room temperature, then washed twice. Finally, the cells were re-suspended in $100 \mu \mathrm{L}$ of $1 \%$ Paraformaldehyde and stored at $4^{\circ} \mathrm{C}$ until acquisition (within 24 hours after staining).

Following staining, data acquisition was done on a Becton Dickson FACScan (BD, San Jose, CA, USA) with WinFCM (Phoenix Flow systems, San Francisco USA) as the acquisition software. Lymphocytes were gated based on FSC and SSC and 20,000 events were acquired. Analysis was done using EXPO software (Phoenix Flow systems, San Francisco USA). Expression level for CD21 and C3dg deposition were reported as median fluorescence.

\section{Quantification of sCD21 by ELISA}

Commercially available enzyme immunoassay kits for sCD21 (Cellsciences, Massachusetts, USA) was used. Plates were supplied pre-coated with a monoclonal antibody specific for CD21. $100 \mu \mathrm{L}$ of serially diluted standards with concentrations that ranged from 3.12-100 units $/ \mathrm{mL}$ and $100 \mu \mathrm{L}$ of plasma samples diluted 1:4 were added to their respective wells followed by the addition of $50 \mu \mathrm{L}$ of a biotinylated monoclonal antibody specific for CD21 to each well and incubated for one hour at $25^{\circ}$ C. At the end of the incubation, the wells were washed twice by adding $300 \mu \mathrm{L}$ of the wash buffer to each well and aspirating. Thereafter, $100 \mu \mathrm{L}$ of streptavidin-HRP was added to each well followed by 30 minutes incubation at room temperature. Unbound enzyme was removed and wells washed by adding and aspirating 300 $\mu \mathrm{L}$ of the wash buffer. $100 \mu \mathrm{L}$ of ready-to-use $3,3^{\prime}, 5,5^{\prime \prime}$ tetramethylbenzidine (TMB) substrate solution was added to each well and incubated at room temperature for 20 minutes in the dark. The reaction was stopped by the addition of $100 \mu \mathrm{L}$ of $0.16 \mathrm{M}$ sulfuric acid and colour intensity read at $415 \mathrm{~nm}$ using the VMax ${ }^{\circledR}$ Kinetic ELISA Microplate Reader (Molecular devices, CA, USA). The concentration of the $\mathrm{SCD} 1$ in the samples was determined by extrapolating from the standard curve.

Statistical analysis was done using Graphad ${ }^{\circledR}$ Prism software Version 5 (CA, USA). 2 tailed paired t-tests were performed with the level of significance set at 0.05 .

\section{Results}

\section{Demographics and clinical data}

The demographics and clinical data for the study participants is shown in Table 1. There was no difference in 
Table 1 Demographics and clinical data of the study participants

\begin{tabular}{llll}
\hline Characteristic & Severe Anaemia & Uncomplicated Malaria & P value \\
\hline Sample size (N) & 30 & 30 & NS \\
\hline Age (months) (Mean \pm SD) & $16.67 \pm 9.217$ & $17.02 \pm 9.5$ & $\mathrm{NS}$ \\
\hline Parasitaemia [Geo mean (95\% Cl)] & $33295(19191-57764)$ & $22196(10387-47432)$ & $\mathrm{ND}$ \\
\hline Hb level (g/dl, mean \pm SD) & $4.5 \pm 1.0$ & $8.9 \pm 1.3$ & 0.04 \\
\hline Absolute lymphocyte count/L (mean \pm S.D) & $9628 \pm 8786$ & $5507.82 \pm 2436$ & \\
\hline
\end{tabular}

NS- Not significant, ND- Not done since $\mathrm{Hb}$ level was one of the recruitment criteria for SMA cases

the mean ages for the SMA and UM malaria group. Although the SMA group had a higher parasite density [Geometric mean (95\% CI)], 33295 (19191-57764) than the UM group 22196 (10387-47432), the difference was not significant. The absolute lymphocyte count was significantly higher for the SMA group $9628 \pm 8786$ as compared to the UM group $5507 \pm 2436(P=0.039)$.

Mature B-cell population, expression level of CD21 and C3dg deposition in severe and uncomplicated malaria Lymphocytes were identified on the basis of their forward scatter (FSC) and side scatter (SSC) characteristics. As shown in Table 1, absolute lymphocyte count was significantly higher in the SMA group $(9628 \pm 8786 \mathrm{SD})$ compared to the UM group $(5,507 \pm 2436 \mathrm{SD}, P=0.04)$.

Figure 1, panel A shows the percentage CD20+ B cells in the two study groups. SMA had a higher mean percentage CD20+ cells $(26.8 \pm 9.7 \mathrm{SD})$ compared to the UM group (20.9 $\pm 9.1 \mathrm{SD}, P=0.03)$ and as shown in Figure 1, panel $\mathrm{B}$, the computed geometric mean numbers of these mature B-cells based on the absolute lymphocyte count was $1,823(1,126$ to $2,982,95 \%$ CI) for SMA and 826.6 (564 to $1,220,95 \% \mathrm{CI}$ )] for UM group $(P=0.003)$.

Figure 1, panel C shows that the SMA group had a statistically significant lower CD21 median fluorescence intensity $(246.4 \pm 87.4 \mathrm{SD})$ compared to the UM controls $(369 \pm 137.7 \mathrm{SD})(P<0.0001)$. Thus although the SMA group had elevated numbers of mature B cells, their expression of membrane-bound CD21 was reduced. Lastly, as shown in Figure 1, panel D, SMAs had a higher percentage of C3dg bearing CD20+ B cells $(18.35 \pm 10$ S.D $)$ compared to UM control $(11.5 \pm 6.8$ $\mathrm{SD}, P=0.0002)$.

\section{Levels of plasma sCD21 in severe and uncomplicated malaria}

Plasma sCD21 was lower in SMA $(246.4 \pm 87.4$ SD units $/ \mathrm{mL}$ ) compared to the UM controls $(341.4 \pm 137.3$ SD, $P<0.0001$ ) (Figure 2).

\section{Discussion}

Previous studies on the pathogenesis of malarial anaemia have focused on the role of RBC complement regulatory proteins on the pathophysiology of severe malaria and have shown a marked reduction of CR1, increased deposition of complement products and increased consumption of complement in children with malarial anaemia [5,27]. Like RBC, B cell is involved in complement processing and has molecules such as CD21, also known as complement receptor 2 (CR2) that share many structural and functional characteristics with RBC CR1. The current study evaluated the effect malaria has on complement regulatory role of $B$ cell.

As has been shown in previous studies [2,3], parasite density cannot be the key cause to severe anaemia, as the parasitaemia for children in the UM group did not differ from those with severe anaemia (Table 1). Children with SMA had increased levels of CD20+ B cells as compared to the UM (Figure 1A), with the B-computed absolute B-cell being also higher in the SMA group (Figure 1B). This expansion in B-cell population is in agreement with previous findings that have shown that B-cell population is increased during malaria [28] leading to strong polyclonal B-cell response and subsequent hyperglobulinaemia [29]. The cystein-rich inter-domain region $1 \alpha($ CIDR $1 \alpha)$ of the PfEMP1 has been incriminated as being the ligand that interacts with $\mathrm{B}$ cells to cause proliferation and activation [25].

Among the many roles of CD21 is to bind the complement split fragment C3dg [30], thus, like RBC CR1, mops up circulating complement products for removal by the reticuloendothelial macrophages. The removal of C3dg by macrophages inadvertently leads to shaving off of CD21 molecules, in a manner analogous to removal of RBC CR1 [31]. As shown in Figure 1C, children with SMA had lower CD21 MFI compared to those with UM. Although the mature B cells were more in SMA than in the UM, the mean level of expression of CD21 was lower (Figure 1C). Reduced CD21 expression has been reported in other diseases such as in SLE, an autoimmune disorder associated with increased levels of circulating immune-complexes [16] and in HIV seropositive individuals [32]. Reduced expression of CD21 may have implications in the mounting of a sufficient immune response since CD21 has been shown to promote the expression of $\mathrm{B}$-cell receptor (BCR) signalling through the formation of CD19/CD21 complex [33], 

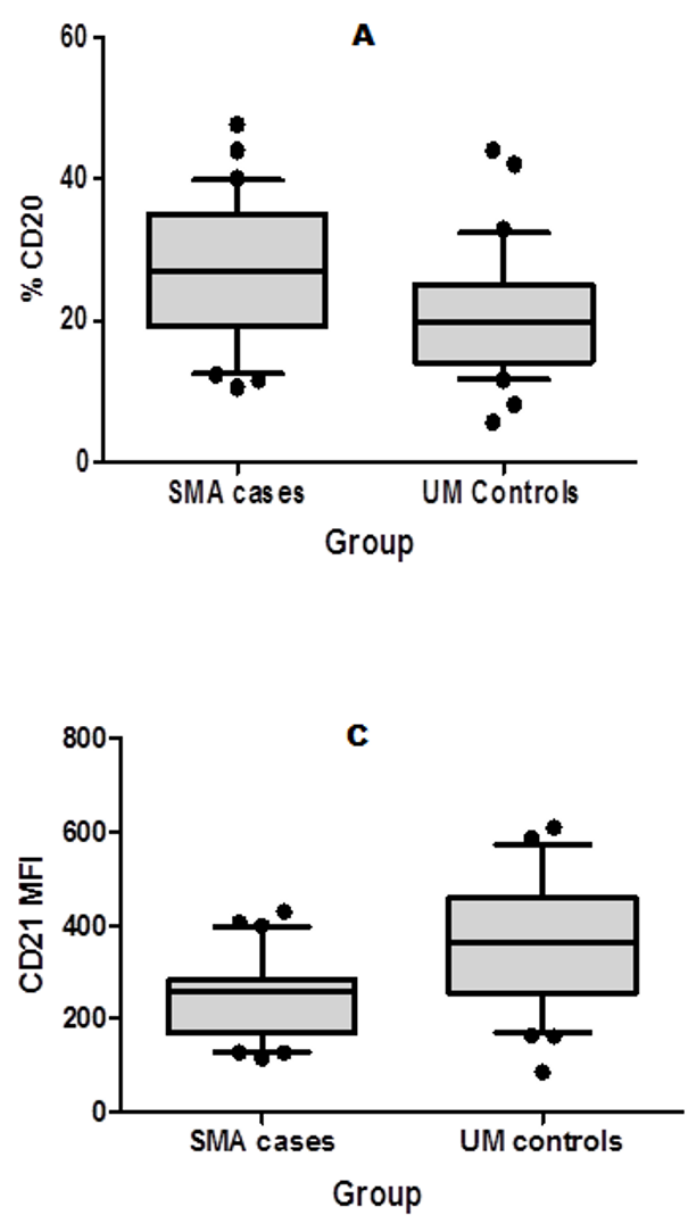
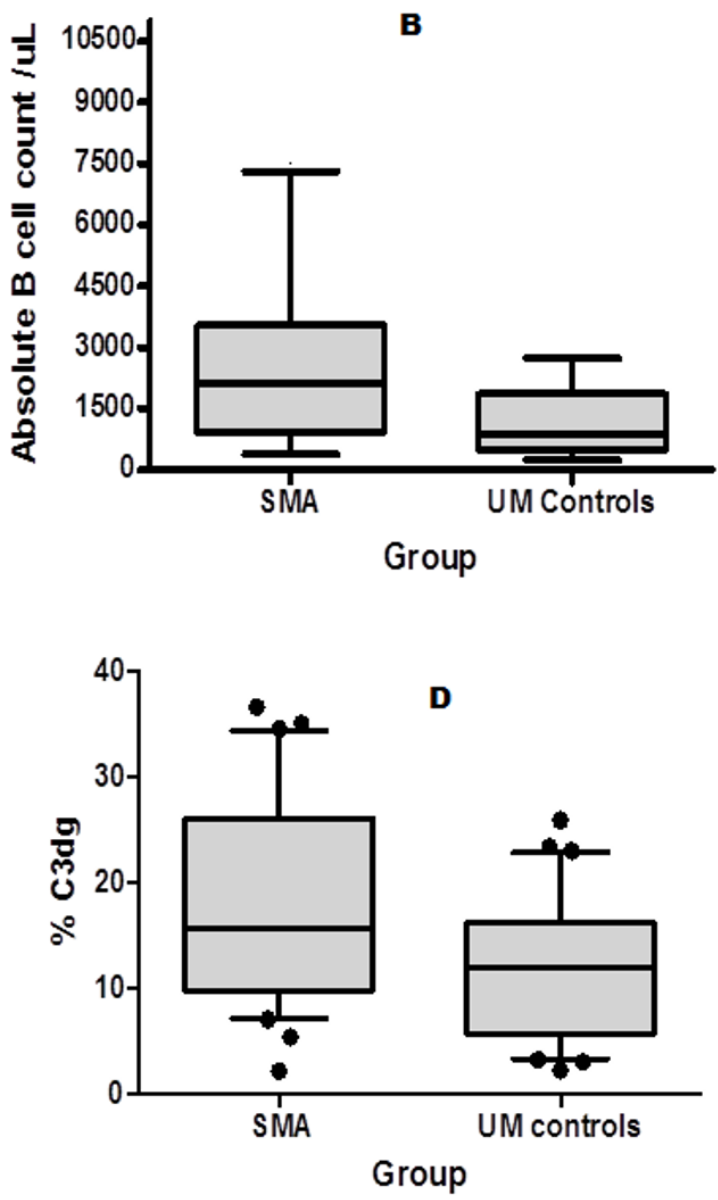

Figure $1 \%$ CD20, absolute cell count, CD21 expression level and C3dg deposition in children with severe (SMA) and uncomplicated malaria (UM). Panel A: Children with SMA had a higher \% of CD20+ B cells compared to UM group $(P=0.03)$. Panel B: Computed absolute Bcell values were higher in children with SMA compared to those with UM $(P=0.003)$. Panel $C$ : The median fluorescent intensity of CD21 was lower in children with SMA compared to the UM controls $(P<0.0001)$. Panel D: B cells of SMA children had a higher percentage of C3dg deposited on their surfaces compared to those in the UM group $(P=0.0002)$.

and thus children with SMA may have impaired humoral response.

Contrary to expectation and as shown in Figure 2, the mean sCD21 was significantly lower in children with SMA compared to UM controls. The expectation would have been that the loss of membrane bound CD21 is by enzymatic cleavage and thus would end up in plasma as sCD21 [34]. The data reported here does not support the enzymatic cleavage assumption, but rather gives credence to the shaving hypothesis which proposes that the accelerated loss of membrane bound CD21 occurs in the reticuloendothelial system during the removal of opsonized ICs [32]. Like malaria, the other diseases that are characterized by immune-complex formation such as juvenile arthritis, SLE and Sjögren's syndrome, have reduced levels of $\mathrm{sCD} 21[35,36]$. $\mathrm{sCD} 21$ retains the capacity to bind $\mathrm{iC} 3 \mathrm{~b}$ and $\mathrm{CD} 23$ [37], and the reduced levels may thus impair responses that are mediated by these ligands.

C3dg is a downstream product of the complement activation and can be used as a surrogate measure of complement activation. As shown in Figure 1D, children in the SMA group had an increased deposition of C3dg on the surface of B cells compared to the UM group. Increased C3dg deposition is a pointer to increased complement activation during SMA. Because it is the deposition of complement product that mediate interaction of B cell with the macrophages, the increased deposition of complement product in SMAs is responsible for shaving of CD21 [38].

\section{Conclusions}

Results from this study show B-cell involvement in the immunopathology of severe malaria anaemia, mainly 


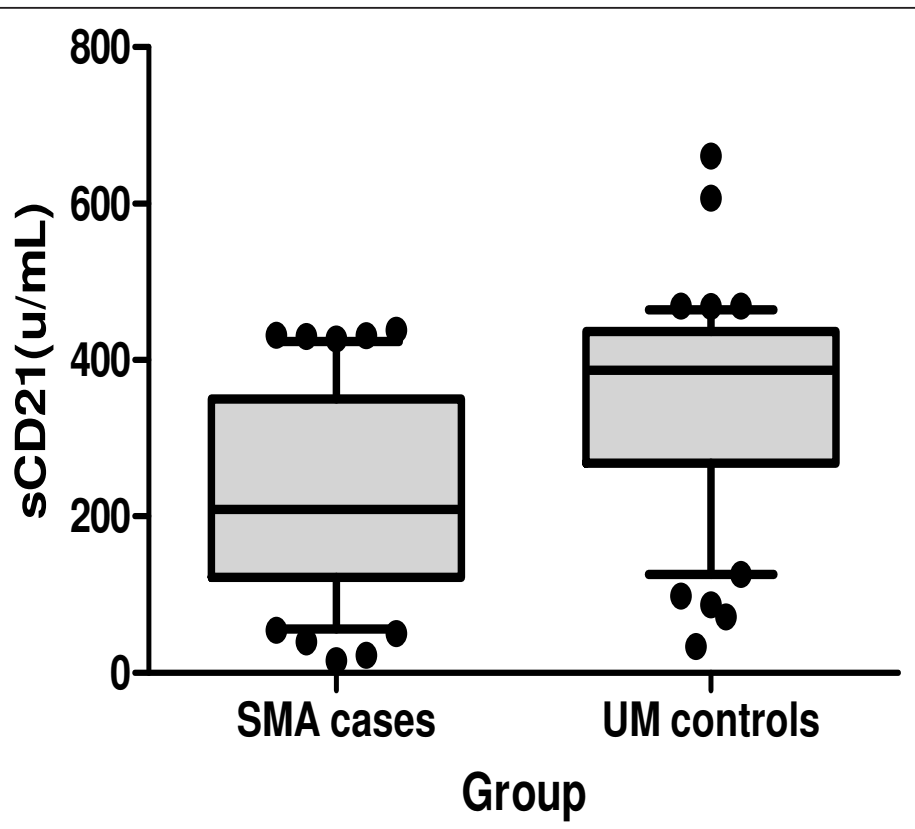

Figure 2 Soluble CD21 levels during malaria. Soluble CD21 (sCD21) were lower in the SMA group compared to UM group $(P<0.0001)$

involving expansion of mature B-cell population, deposition of C3dg and the loss of both membrane bound and soluble CD21. Interestingly, the loss of membranebound CD21 is not through the classical enzymatic cleavage, but probably involves interaction of CD21 loaded with C3dg with cells of reticuloendothelial system, in a manner analogous to removal of C3b bearing CR1 on red blood cells.

\section{Acknowledgements}

We wish to thank the parents of the children who were enrolled in this study. We are grateful to Dr Ronald P Taylor, Department of Biochemistry and Molecular Genetics, University of Virginia School of Medicine,

Charlottesville for advice and gracious donation of the antibodies used in the study. We thank project staff, including laboratory technicians, drivers and medical staff. Jackson Cheruiyot was a PhD student at Jomo Kenyatta University of Agriculture and Technology and was supported by the D43 $\mathrm{NIH}$ training grant. This work is published with the permission of the Director, Kenya Medical Research Institute.

The U.S. Government has the right to retain a non-exclusive, royalty-free license in and to any copyright covering this paper.

Disclaimer

The opinions or assertions contained herein are the private views of the authors, and are not to be construed as official, or as reflecting true views of the Department of the Army or the Department of Defense.

\section{Author details}

'Walter Reed Project/Kenya Medical Research Institute, Kisumu, Kenya. ${ }^{2}$ Jomo Kenyatta University of Agriculture and Technology, Nairobi, Kenya. ${ }^{3}$ Masinde Muliro University of Science and Technology, Kakamega, Kenya. ${ }^{4}$ Kenya Medical Research Institute, Nairobi, Kenya.

\section{Authors' contributions}

JCK was a graduate student in Jomo Kenyatta University of Agriculture and Technology, Nairobi, Kenya. He conducted all the experiments, helped in data analysis and drafted the manuscript. Both JKM were university supervisors to JCK and assisted in study design and edited the manuscript.
JNW designed the study, supervised the work and helped in drafting the final manuscript. All authors have read and approved the final manuscript.

\section{Competing interests}

The authors declare that they have no competing interests.

Received: 9 December 2011 Accepted: 9 March 2012

Published: 9 March 2012

\section{References}

1. WHO: World malaria report 2008 Geneva: World Health Organization; 2008.

2. Mackintosh $\mathrm{CL}$, Beeson JG, Marsh K: Clinical features and pathogenesis of severe malaria. Trends Parasitol 2004, 20:597-603.

3. Miller LH, Good MF, Milon G: Malaria pathogenesis. Science 1994, 264:1878-1883.

4. Stoute JA, Odindo AO, Owuor BO, Mibei EK, Opollo MO, Waitumbi JN: Loss of red blood cell-complement regulatory proteins and increased levels of circulating immune complexes are associated with severe malarial anemia. J Infect Dis 2003, 187:522-525.

5. Waitumbi JN, Opollo MO, Muga RO, Misore AO, Stoute JA: Red cell surface changes and erythrophagocytosis in children with severe Plasmodium falciparum anemia. Blood 2000, 95:1481-1486.

6. Devine DV: The regulation of complement on cell surfaces. Transfus Med Rev 1991, 5:123-131.

7. Arvieux J, Yssel H, Colomb MG: Antigen-bound C3b and C4b enhance antigen-presenting cell function in activation of human T-cell clones. Immunology 1988, 65:229-235.

8. Thornton BP, Vetvicka $V$, Ross GD: Function of C3 in a humoral response: $\mathrm{iC} 3 \mathrm{~b} / \mathrm{C} 3 \mathrm{dg}$ bound to an immune complex generated with natural antibody and a primary antigen promotes antigen uptake and the expression of co-stimulatory molecules by all B cells, but only stimulates immunoglobulin synthesis by antigen-specific B cells. Clin Exp Immunol 1996, 104:531-537.

9. Pangburn MK, Pangburn KL, Koistinen V, Meri S, Sharma AK: Molecular mechanisms of target recognition in an innate immune system: interactions among factor $\mathrm{H}, \mathrm{C} 3 \mathrm{~b}$, and target in the alternative pathway of human complement. J Immunol 2000, 164:4742-4751.

10. Thornton BP, Vetvicka $V$, Ross GD: Natural antibody and complementmediated antigen processing and presentation by $B$ lymphocytes. J Immunol 1994, 152:1727-1737. 
11. Cherukuri A, Dykstra M, Pierce SK: Floating the raft hypothesis: lipid rafts play a role in immune cell activation. Immunity 2001, 14:657-660.

12. Tedder TF, Zhou $L$, Engel P: The CD19/CD21 signal transduction complex of B lymphocytes. Immunol Today 1994, 15:437-442.

13. Boyd AW, Anderson KC, Freedman AS, Fisher DC, Slaughenhoupt B, Schlossman SF, Nadler LM: Studies of in vitro activation and differentiation of human B lymphocytes. I. Phenotypic and functional characterization of the B cell population responding to anti-lg antibody. J Immunol 1985, 134:1516-1523.

14. Timens W, Boes A, Poppema S: Human marginal zone B cells are not an activated $B$ cell subset: strong expression of $\mathrm{CD} 21$ as a putative mediator for rapid B cell activation. Eur J Immunol 1989, 19:2163-2166.

15. Holme E, Fyfe A, Zoma A, Veitch J, Hunter J, Whaley K: Decreased C3b receptors (CR1) on erythrocytes from patients with systemic lupus erythematosus. Clin Exp Immunol 1986, 63:41-48.

16. Prodeus AP, Goerg S, Shen LM, Pozdnyakova OO, Chu L, Alicot EM, Goodnow CC, Carroll MC: A critical role for complement in maintenance of self-tolerance. Immunity 1998, 9:721-731.

17. Walport MJ, Lachmann PJ: Erythrocyte complement receptor type 1, immune complexes, and the rheumatic diseases. Arthritis Rheum 1988, 31:153-158.

18. Wilson JG, Ratnoff WD, Schur PH, Fearon DT: Decreased expression of the $\mathrm{C} 3 \mathrm{~b} / \mathrm{C} 4 \mathrm{~b}$ receptor (CR1) and the C3d receptor (CR2) on B lymphocytes and of CR1 on neutrophils of patients with systemic lupus erythematosus. Arthritis Rheum 1986, 29:739-747.

19. Myones BL, Ross GD: Identification of a spontaneously shed fragment of B cell complement receptor type two (CR2) containing the C3d-binding site. Complement 1987, 4:87-98.

20. Ling N, Hansel T, Richardson P, Brown B: Cellular origins of serum complement receptor type 2 in normal individuals and in hypogammaglobulinaemia. Clin Exp Immunol 1991, 84:16-22.

21. Huemer HP, Larcher C, Prodinger WM, Petzer AL, Mitterer M, Falser N: Determination of soluble CD21 as a parameter of B cell activation. Clin Exp Immunol 1993, 93:195-199.

22. Tooze JA, Bevan DH: Decreased expression of complement receptor type 2 (CR2) on neoplastic B cells of chronic lymphocytic leukaemia. Clin Exp Immunol 1991, 83:423-429.

23. Lowe J, Brown B, Hardie D, Richardson P, Ling N: Soluble forms of CD21 and CD23 antigens in the serum in B cell chronic lymphocytic leukaemia. Immunol Lett 1989, 20:103-109.

24. Abele DC, Tobie JE, Hill GJ, Contacos PG, Evans CB: Alterations in Serum Proteins and 19s Antibody Production during the Course of Induced Malarial Infections in Man. Am J Trop Med Hyg 1965, 14:191-197.

25. Donati D, Mok B, Chene A, Xu H, Thangarajh M, Glas R, Chen Q Wahlgren M, Bejarano MT: Increased $B$ cell survival and preferential activation of the memory compartment by a malaria polyclonal $\mathrm{B}$ cell activator. J Immunol 2006, 177:3035-3044.

26. Nyakoe NK, Taylor RP, Makumi JN, Waitumbi JN: Complement consumption in children with Plasmodium falciparum malaria. Malar $J$ 2009, 8:7.

27. Stoute JA, Odindo AO, Owuor BO, Mibei EK, Opollo MO, Waitumbi JN: Loss of red blood cell-complement regulatory proteins and increased levels of circulating immune complexes are associated with severe malarial anemia. J Infect Dis 2003, 187:522-525.

28. Adu D, Williams DG, Quakyi IA, Voller A, Anim-Addo Y, Bruce-Tagoe AA, Johnson GD, Holborow EJ: Anti-ssDNA and antinuclear antibodies in human malaria. Clin Exp Immunol 1982, 49:310-316.

29. Tobie JE, Abele DC, Wolff SM, Contacos PG, Evans CB: Serum immunoglobulin levels in human malaria and their relationship to antibody production. J Immunol 1966, 97:498-505.

30. Prodinger WM, Schwendinger MG, Schoch J, Kochle M, Larcher C, Dierich MP: Characterization of C3dg binding to a recess formed between short consensus repeats 1 and 2 of complement receptor type 2 (CR2; CD21). J Immunol 1998, 161:4604-4610.

31. Craig ML, Waitumbi JN, Taylor RP: Processing of C3b-opsonized immune complexes bound to non-complement receptor 1 (CR1) sites on red cells: phagocytosis, transfer, and associations with CR1. J Immunol 2005, 174:3059-3066.

32. Scott ME, Landay AL, Lint TF, Spear GT: In vivo decrease in the expression of complement receptor 2 on B-cells in HIV infection. AIDS 1993, 7:37-41.
33. Cheng PC, Cherukuri A, Dykstra M, Malapati S, Sproul T, Chen MR, Pierce SK: Floating the raft hypothesis: the roles of lipid rafts in B cell antigen receptor function. Semin Immunol 2001, 13:107-114.

34. Ling N, Hansel T, Richardson P, Brown B: Cellular origins of serum complement receptor type 2 in normal individuals and in hypogammaglobulinaemia. Clin Exp Immunol 1991, 84:16-22.

35. Masilamani M, Nowack R, Witte T, Schlesier M, Warnatz K, Glocker MO, Peter HH, lllges $\mathrm{H}$ : Reduction of soluble complement receptor 2/CD21 in systemic lupus erythomatosus and Sjogren's syndrome but not juvenile arthritis. Scand J Immunol 2004, 60:625-630.

36. Masilamani M, von Kempis J, Illges H: Decreased levels of serum soluble complement receptor-II (CR2/CD21) in patients with rheumatoid arthritis. Rheumatology (Oxford) 2004, 43:186-190.

37. Fremeaux-Bacchi V, Kolb JP, Rakotobe S, Kazatchkine MD, Fischer EM: Functional properties of soluble CD21. Immunopharmacology 1999, 42:31-37.

38. Fremeaux-Bacchi V, Bernard I, Maillet F, Mani JC, Fontaine M, Bonnefoy JY, Kazatchkine MD, Fischer E: Human lymphocytes shed a soluble form of CD21 (the C3dg/Epstein-Barr virus receptor, CR2) that binds iC3b and CD23. Eur J Immunol 1996, 26:1497-1503.

doi:10.1186/1475-2875-11-66

Cite this article as: Korir et al: B-cell activity in children with malaria. Malaria Journal 2012 11:66.

\section{Submit your next manuscript to BioMed Central and take full advantage of:}

- Convenient online submission

- Thorough peer review

- No space constraints or color figure charges

- Immediate publication on acceptance

- Inclusion in PubMed, CAS, Scopus and Google Scholar

- Research which is freely available for redistribution

Submit your manuscript at www.biomedcentral.com/submit
Ciomed Central 